\title{
Bromatological and fermentative characteristics of elephant grass silages with the addition of annato by-product ${ }^{1}$
}

\author{
Margareth Maria Teles Rêgo ${ }^{2}$, José Neuman Miranda Neiva ${ }^{3}$, Maria Andréa Borges \\ Cavalcante $^{4}$, Magno José Duarte Cândido ${ }^{5}$, Rossana Herculano Clementino ${ }^{5}$, João Restle ${ }^{6}$ \\ 1 Projeto financiado pela CAPES-PROCAD, CNPq e FUNCAP. \\ 2 Universidade Federal do Rio Grande do Norte. Bolsista do CNPq. \\ 3 Universidade Federal do Tocantins. Bolsista do CNPq. \\ ${ }^{4}$ ADAGRI-CE. \\ 5 Universidade Federal do Ceará. Bolsista do CNPq \\ ${ }^{6}$ Universidade Federal de Goiás. Bolsista do CNPq
}

ABSTRACT - The objective of the present study was to evaluate the nutritional value of elephant grass (Pennisetum purpureum, Schum.) silages with the addition of $0 ; 4 ; 8 ; 12$ and $16 \%$ of the by-product from SPU annato (Bixa orellana, L.) based on natural matter. A complete random design was used with four replications. The nutritional composition, $\mathrm{pH}$, ammonical nitrogen and lactic, acetic, propyonic and butyric acids were determined. Levels of annato by-product had an increasingly linear effect on contents of dry matter, organic matter, crude protein, ether extract, non-fibrous carbohydrates, propionic acid and ammonical nitrogen. The insoluble nitrogen contents in detergent and acid detergent, calculated on the percentage of total nitrogen and lactic, acetic and butyric acids were not altered by adding the annato by product. The annatto by-product improves the bromatological characteristics of the silages and it can be added in levels up to $16 \%$ of the natura matter at the moment of elephant grass ensilage.

Key Words: Bixa orellana, by-product, ensilage, fermentation

\section{Características bromatológicas e fermentativas da silagem de capim- elefante contendo subproduto do urucum}

RESUMO - O trabalho foi conduzido com o objetivo de avaliar o valor nutritivo das silagens de capim-elefante (Pennisetum purpureum, Schum.) com adição de $0 ; 4 ; 8 ; 12$ e 16\% de subproduto do processamento do urucum (Bixa orellana, L.) SPU, com base na matéria natural. Utilizou-se delineamento inteiramente casualizado com quatro repetições Determinaram-se a composição nutricional, valores de $\mathrm{pH}$, nitrogênio amoniacal e ácido lático, acético, propiônico e butírico. Os níveis do subproduto de urucum tiveran efeito linear crescente sobre os teores de matéria seca, matéria orgânica, proteína bruta, extrato etéreo, carboidratos não-fibrosos, ácido propiônico e nitrogênio amonical. Os teores nitrogênio insolúvel em detergente e em detergente ácido, calculados em porcentagem de nitrogênio total e os ácidos lático, acético e butírico não foram alterados com a adição do subproduto do urucum. Os teores de fibra em detergente neutro, fibra em detergente ácido e carboidratos totais reduzidos decresceram linearmente com a adição do subproduto do urucum. O subproduto de urucum melhora as características bromatológicas das silagens e podem ser adicionado em níveis de até $16 \%$ da matéria natural no momento da ensilagem do capim-elefante.

Palavras-chave: Bixa orellana, ensilagem, fermentação, subproduto

\section{Introduction}

Elephant grass (Pennisetum purpureum Schum.) is an important grass found throughout tropical and subtropical regions in the world (Tcacenco \& Botrel, 1997). However, its use is limited because it only has good nutritive value in the rainy season when there is a good offer of forage in the pastures. When there is a greater demand for forage to supplement the animals in the dry season, it is old and it has little nutritive value.

To make full use of elephant grass in the period of food scarcity, some conservation practices are necessary such as ensilage to guarantee the preservation of the forage quality. However, when the production and forage quality are well balanced, elephant grass presents limiting moisture content levels for proper fermentation (Nussio et al., 2002). 
Several techniques have been assessed to solve the problem of high moisture. Addition of absorbent products has been studied to raise the matter contents of the ensiled mass of tropical grasses (Evangelista et al., 2000; Neiva et al., 2006; Coan et al., 2007; Tavares et al., 2009; Ribeiro et al., 2009). The assessed absorbent materials include byproducts from fruit processing or harvest, materials that are normally discarded by the processing industries.

Studies that assessed fruit processing by-products as additives to elephant grass silage include those by Cysne et al. (2006), Pompeu et al. (2006), Sá et al.(2007), Candido et al.(2007) and Ferreira et al.(2007b), who studied byproducts of graviola, pineapple, mango, passion fruit and cashew bagasse, respectively. All these authors observed alterations in the chemical and fermentation composition of the studied silages and showed that these materials presented characteristics that can improve the chemical and fermentative characteristics of the silages produced with high moisture content grasses.

Annato (Bixa orellana L.) is a plant native to tropical forests, cultivated in a few countries in the world (Souza \& Faria, 2000). Approximately 2,500 tons of annato by-product, after extracting bixine, are obtained in Brazil, mainly in the northeastern region, where about $97 \%$ of the residue is not used (Souza \& Faria, 2000).

Due to the possibility of raising the dry matter content of elephant grass forage for ensilage, the present study assessed the chemical and fermentative characteristics of elephant grass silage containing by-product of annato.

\section{Material and Methods}

The experiment was carried out in the Núcleo de Pesquisa em Forragicultura in the Departamento de Zootecnia at the Universidade Federal do Ceará (UFC), in Fortaleza, CE.

Five addition levels (0.4.8. 12 and 16.0\%) of the byproduct from annato (SPU) (Bixa orellana L.) processing were studied, based on the natural material at elephant grass ensilage. A complete randomized design with four replications was used.

Elephant grass was used to make the experimental silage from a grass paddock that after a standardizing cut was mulched with $50 \mathrm{~kg} \mathrm{~N}$ and $40 \mathrm{~kg} \mathrm{~K}_{2} \mathrm{O}$ in the form of urea and potassium chloride, respectively. The grass was manually cut after 70 days of growth and processed in a conventional forage chopper regulated to cut in $1-$ or $2-\mathrm{cm}$ particles The annato by-product from seed processing to extract bixine was then added.

The annato by-product was obtained from Serra Grande agroindustrial after extracting bixine from the annato seeds.
The material obtained in the processing plant was ground in a hammer grinder with a $0.2 \mathrm{~cm}$ mesh sieve. Plastic 210 -L drums were used as experimental silos and $126 \mathrm{~kg}$ forage was placed in each silo to reach $600 \mathrm{~kg} / \mathrm{m}^{3}$ density.

At ensilage, the elephant grass presented $22.01 \%$ dry matter (DM), $88.51 \%$ organic matter (OM), $5.00 \%$ crude protein (CP), $77.31 \%$ neutral detergent fiber (NDF), $48.08 \%$ acid detergent fiber (FDA), 29.23\% hemicellulose, 3.90\% either extract (EE), 79.61\% total carbohydrates (CHOT), $2.30 \%$ non-fibrous carbohydrates (CNF), $48.70 \%$ neutral detergent insoluble nitrogen (NIDN, \% total N) and $16.23 \%$ acid detergent insoluble nitrogen (NIDA, $\%$ total $\mathrm{N}$ ). The annatto by-product presented $92.87 \%$ dry matter, $92.92 \%$ organic matter, $16.61 \%$ crude protein, $42.44 \%$ neutral detergent fiber, $22.25 \%$ acid detergent fiber, $20.19 \%$ hemicellulose, $7.16 \%$ ether extract, $69.15 \%$ total carbohydrates, $26.71 \%$ non-fibrous carbohydrates, $34.94 \%$ neutral detergent insoluble nitrogen $(\%$ total $\mathrm{N})$ and $12.21 \%$ acid detergent insoluble nitrogen ( $\%$ total $\mathrm{N})$, based on the dry matter.

After 65 days, the silos were opened and homogeneous $300 \mathrm{~g}$ samples were removed and stored in a freezer at $-10^{\circ} \mathrm{C}$ until chemical and bromatological analyses were made. The samples were removed from the upper, mid and lower third thirds of the drums and were thoroughly homogenized.

In the Laboratório de Nutrição Animal at the Departamento de Zootecnia at the Universidade Federal do Ceará the samples were pre-dried in a forced circulation chamber at $55^{\circ} \mathrm{C}$ and ground in a grinder with $1 \mathrm{~mm}$ mesh sieve for later determination of the dry matter, organic matter, crude protein, neutral detergent fiber, acid detergent fiber, ether extract, neutral detergent insoluble nitrogen $(\%$ total $\mathrm{N})$ and acid detergent insoluble nitrogen, following methodology by Silva \& Queiroz (2002). The total carbohydrate values were obtained by the difference, according to the methodology by Sniffen et al. (1992), where CHT $(\%)=100-(\% \mathrm{~PB}+\% \mathrm{EE}+\% \mathrm{ash})$. The non-fibrous carbohydrate contents were calculated from the difference between the fibrous carbohydrates and neutral detergent fiber, according to Hall (2001).

The $\mathrm{pH}$ value was determined following Silva \& Queiroz (2002) and the $\mathrm{N}^{-\mathrm{NH}_{3}}$ content ( $\%$ total $\mathrm{N}$ ) was determined according to methodlogy by Bolsen et al. (1992), adapted by Cândido (2000).

The silage juice was collected using a hydraulic press to determine the organic acids and $50 \mathrm{~mL}$ juice was placed in recipients containing $10 \mathrm{~mL}$ phosphoric solution at $25 \%$, which after buffering, were placed in a freezer at $-10^{\circ} \mathrm{C}$ for later analysis. 
The organic acid (lactic, acetic, propyonic and butyric) concentrations were determined in the Laboratório de Polímeros at the Departamento de Química Orgânica e Inorgânica at the Universidade Federal do Ceará. After thawing the samples, $5 \mathrm{~mL}$ was transferred to $10 \mathrm{~mL}$ centrifuge tubes (Sigma Laboratory Centrifuges 4k15) and centrifuged at $5000 \mathrm{rpm}$ at $10^{\circ} \mathrm{C}$ for 15 minutes. The organic acids were determined by high performance liquid phase chromatography (HPLC) following methodology by Mathew et al. (1997), filtering $2 \mathrm{~mL}$ supernatant of each silage juice sample through cellulose acetate membrane with $0.45 \mu \mathrm{m}$ porosity.

The HPLC analyses were carried out using a Phenomenex, Rezex $8 \mathrm{~m} \mu 8 \% \mathrm{H}^{+}$column $300 \mathrm{~mm}$ long and $7.8 \mathrm{~mm}$ wide, $\mathrm{H}_{2} \mathrm{SO}_{4}$ at $8 \mathrm{mM}$ aqueous solvent solution and $0.5 \mathrm{~mL} /$ minute elution rate. The equipment was calibrated by injecting standard solutions containing 10-50 mM lactic acid/L, 10-60 $\mathrm{mM}$ acetic acid/L, 15-150 $\mathrm{mM}$ propyonic acid 10-50mM butyric acid, and the standards were also filtred through cellulose acetate membrane with $0.45 \mu \mathrm{m}$ porosity. Organic concentration peaks of the silage juice samples were obtained from their areas in relation to the calibration curve for each standard injected, using the Origin 6.0 Profissional Software.

The obtained data were first analyzed to meet the assumptions of normality, additivity and homocedasticity. The data obtained for $\mathrm{N}-\mathrm{NH}_{3}(\%$ total $\mathrm{N})$ were transformed to $\left(\log _{10} \mathrm{~N}-\mathrm{NH}_{3}\right)$ for regression analysis.

Analysis of variance and regression were carried out on the data for the silage chemical and fermentative characteristics. The models were chosen based on the significance of the linear and quadratic coefficients by the Student $t$ test, at the levels of $1 \%$ and $5 \%$ probability. The PROC REG procedure of the SAS Software (2001) was adopted as a tool in the statistical analyses.

\section{Results and Discussion}

The addition of the annato by-product to elephant grass silage raised the dry matter contents of the silage $(\mathrm{P}<0.01)$ and for each $1 \%$ included there was a 0.61 percentage point increase in the silage dry matter contents (Table 1). This result was expected because, as it was previously seen, the annato by-product dry matter contents (92.87\%) were greater than the elephant grass dry matter contents $(22.01 \%)$ and therefore its addition would raise the dry matter contents of the silage.

The values observed in the present study were close to those reported by several authors. Gonçalves et al. (2006) and Gonçalves et al. (2004) observed 0.56 and 0.55 percentage point increases in the dry matter content of elephant grass silages for every $1 \%$ annato and Caribbean cherry by-product added, respectively. Each $1 \%$ addition of coffee hulls to elephant grass silage raised the dry matter contents by 0.69 percentage points (Bernardino et al., 2005).

Further, in agreement with the regression study, it was observed that the addition of $10.4 \%$ annato byproduct to elephant grass silage resulted in $28 \%$ dry matter content, which according to McCullough (1977), guarantees good fermentation of the silage forage. It is known that low dry matter contents favor low osmotic pressure, leading to the development of Clostridium genus bacteria that break down sugars, lactic acid, protein and amino acids into butyric and acetic acid, ammonia and carbonic gas, resulting in a significant reduction in the silage quality (McDonald, 1981), its acceptability and intake (Wilkinson, 1983). Thus, the addition of $10.4 \%$ or more annato by-product was sufficient to prevent undesirable fermentation.

It is important to point out that the effect of raising the silage dry matter content on clostridic bacteria growth did not occur only after the levels mentioned above were met. According to Muck (1988), the water activity decreases progressively with increase in the dry matter contents, causing a proportional reduction in the microorganism growth, mainly of the Clostridium genus. Thus, adding annato by-product favored the fermentation process even if the ideal dry matter contents were not attained.

Crude protein content was increased $(\mathrm{P}<0.01)$ at 1.16 percentage point by the inclusion of each $1 \%$ annato byproduct to elephant grass silage (Table 1 ). According to the regression equation, adding $5.75 \%$ annato by-product to the elephant grass silage was sufficient to meet the level of $7 \%$ crude protein. Although it is known that the protein level by itself does not guarantee good ruminal fermentation, $7 \%$ crude protein has been reported as the minimum necessary for good ruminal fermentation (Silva \& Leão, 1979). However, care should be taken because part of the nitrogen present in by-products is in the form of acid detergent insoluble nitrogen. In the case of the present study, the acid detergent insoluble nitrogen contents in the annato by-product (12.21\%) were lower than those observed in the elephant grass (16.23\%) from which it was deduced that its addition would not alter the availability of crude protein to ruminal microorganisms.

Several researchers have observed increase in the crude protein contents in silages with the addition of byproducts from fruit cultivation. Gonçalves et al. $(2004,2006$, 2007) and Ferreira (2007a) worked with levels of by-product addition from guava, annatto, cashew penducle and 
Table 1 - Chemical compositions of elephant grass silage containing annato by-product

\begin{tabular}{|c|c|c|c|c|c|c|c|c|}
\hline & \multicolumn{5}{|c|}{ Annato by-product (\%) } & \multirow[t]{2}{*}{ Regression } & \multirow[t]{2}{*}{$\mathrm{R}^{2}$} & \multirow{2}{*}{$\begin{array}{l}\mathrm{CV} \\
(\%)\end{array}$} \\
\hline & 0 & 4 & 8 & 12 & 16 & & & \\
\hline Dry matter $(\%)$ & 22.03 & 23.03 & 27.38 & 28.76 & 31.29 & $\hat{\mathrm{Y}}=21.65+0.61 \mathrm{x} * *$ & 0.90 & 4.27 \\
\hline Crude protein $(\%)$ & 5.87 & 6.98 & 7.07 & 8.60 & 8.22 & $\hat{\mathrm{Y}}=6.08+0.16 \mathrm{x} * *$ & 0.70 & 8.05 \\
\hline Neutral detergent fiber $(\%)$ & 73.68 & 70.84 & 69.75 & 66.78 & 67.00 & $\hat{Y}=73.09-0.43 x^{*} *$ & 0.72 & 2.22 \\
\hline Acid detergent fiber $(\%)$ & 48.12 & 44.13 & 43.72 & 42.57 & 40.43 & $\hat{\mathrm{Y}}=47.18-0.42 \mathrm{x} * *$ & 0.74 & 3.28 \\
\hline Hemicellulose $(\%)$ & 25.56 & 26.71 & 26.02 & 24.22 & 26.56 & $\hat{\mathrm{Y}}=25.81 \pm 1.31$ & - & 5.07 \\
\hline Total carbohydrates $(\%)$ & 81.36 & 79.95 & 79.77 & 78.83 & 79.34 & $\hat{\mathrm{Y}}=80.89-0.13 \mathrm{x} * *$ & 0.39 & 1.12 \\
\hline Nonfibrous carbohydrates $(\%)$ & 7.69 & 9.11 & 10.03 & 12.04 & 12.33 & $\hat{Y}=7.80+0.30 x * *$ & 0.64 & 12.70 \\
\hline Neutral detergent insoluble nitrogen ( $\%$ total $\mathrm{N})$ & 27.84 & 26.77 & 27.20 & 26.30 & 28.36 & $\hat{\mathrm{Y}}=27.29 \pm 2.49$ & - & 9.11 \\
\hline Acid detergent insoluble nitrogen $(\%$ total $\mathrm{N})$ & 18.03 & 15.83 & 15.67 & 14.15 & 16.32 & $\hat{\mathrm{Y}}=18.07 \pm 3.01$ & 0.33 & 9.35 \\
\hline Ether extract $(\%)$ & 2.13 & 2.51 & 3.19 & 3.18 & 3.29 & $\hat{\mathrm{Y}}=2.27+0.07 \mathrm{x} * *$ & 0.62 & 11.53 \\
\hline
\end{tabular}

** $1 \%$ probability.

pineapple in elephant grass silage, respectively and observed increases in the crude protein contents.

The addition of annato by-product decreased $(\mathrm{P}<0.01)$ neutral detergent fiber and acid detergent fiber contents in the silage (Table 1) but it did not alter the hemicellose contents $(\mathrm{P}<0.05)$. Neutral detergent fiber and acid detergent fiber decreased 0.43 and 0.42 percentage points, respectively, for each $1 \%$ annato by-product added to the elephant grass silage. These reductions can be explained by the smaller neutral detergent fiber and acid detergent fiber contents in the annato by-product ( $42.44 \%$ neutral detergent fiber and $22.25 \%$ acid detergent fiber) compared to elephant grass $(77.31 \%$ neutral detergent fiber and $48.08 \%$ acid detergent fiber). The reduction in the silage neutral detergent fiber contents may contribute to increase the dry matter intake (Resende et al., 1994), and the energetic density of the ruminant feed (Jung \& Allen, 1995). However, although this increase in intake may occur, it is important to remember that other factors interact to determine the dry matter intake of a bulk food, including the crude protein contents.

Total carbohydrate content decreased with the addition of annato by-product to the silage $(\mathrm{P}<0.01)$, with 0.13 percentage point reduction for each $1 \%$ annato by-product added (Table 1), which was justified by the smaller total carbohydrate content of the annato by-product (69.15\%) compared to elephant grass (79.61\%). Decrease in the silage total carbohydrate contents was also associated to decrease in the silage neutral detergent fiber and acid detergent fiber contents that may contribute to improving their intake and digestibility.

For every $1 \%$ of annato by-product added, a 0.30 percentage point increase was estimated in non-fibrous carbohydrate contents of the silage (Table 1). This result was expected because the annato by-product has a greater non-fibrous carbohydrate content $(26.71 \%)$ than elephant grass $(2.30 \%)$. However, a 4.69 percentage point increase was observed when the non-fibrous carbohydrates contents of the pre-ensilaged elephant grass $(62.30 \%)$ were compared with the silages of elephant grass alone (7.69\%). According to Tosi et al. (1999), increases in the non-fibrous carbohydrate contents may be associated to the break of chemical links of the structural carbohydrates, especially hemicellose. The hemicellose contents of the pre-silage elephant grass $(29.23 \%)$ were greater than the contents of the elephant grass silage (25.56\%) showing that part of the hemicellose disappeared. This disappearance may also have been due to the action of microorganisms during the fermentation process (McCullough, 1977). Nonfibrous carbohydrates are highly digestible carbohydrates (Van Soest, 1994) and they serve as substrates for the Lactobacillus genus bacteria to improve silage quality and energetic value.

The neutral detergent insoluble nitrogen contents $(\%$ total $\mathrm{N})$ and acid detergent insoluble nitrogen (NIDA, $\%$ total $\mathrm{N}$ ) were altered by the addition of annato by-product $(\mathrm{P}<0.05)$ and they presented average values of $27.29 \% \pm$ 2.49 and $18.07 \% \pm 3.01$ (Table 1). The ensilage process modified the neutral detergent insoluble nitrogen and acid detergent insoluble nitrogen ( $\%$ total $\mathrm{N})$ ) of the silage, because the pre-silage contents in the elephant grass were $48.70 \%$ and $16.23 \%$, respectively, and in the annato byproduct they were 34.924 and $12.21 \%$, respectively. Thus, it was observed a reduction in the neutral detergent insoluble nitrogen and acid detergent insoluble nitrogen after ensilage that probably resulted from the enzymes present in the silage acting on the nitrogen linked to the neutral detergent fiber and acid detergent fiber that resulted in the reduction of the contents of these components in the silage. As the nitrogen linked to the neutral detergent fiber was presented in a less complex form, the greatest action occurred in this fraction. 
Table 2 - Vakues of $\mathrm{pH}$, contents of ammonical nitrogen and lactic, acetic, propyonic and butyric acids of elephant grass silage containing annato by-product

\begin{tabular}{|c|c|c|c|c|c|c|c|c|}
\hline & \multicolumn{5}{|c|}{ Addition level (\%) SPU } & \multirow[t]{2}{*}{ Regression } & \multirow[t]{2}{*}{$\mathrm{R}^{2}$} & \multirow{2}{*}{$\begin{array}{l}\text { CV } \\
(\%)\end{array}$} \\
\hline & 0 & 4 & 8 & 12 & 16 & & & \\
\hline $\mathrm{pH}$ & 3.85 & 3.90 & 3.90 & 4.13 & 4.01 & $\hat{\mathrm{Y}}=3.85+0.01 \mathrm{x} * *$ & 0.29 & 2.86 \\
\hline Lactic acid $^{1}$ & 3.97 & 4.64 & 5.26 & 3.95 & 4.15 & $\hat{\mathrm{Y}}=4.40 \pm 0.86$ & - & 19.49 \\
\hline Acetic acid $^{1}$ & 0.40 & 0.38 & 0.53 & 0.42 & 0.59 & $\hat{\mathrm{Y}}=0.47 \pm 0.15$ & - & 32.70 \\
\hline Propyonic acid ${ }^{1}$ & 0.19 & 0.22 & 0.36 & 0.22 & 0.39 & $\hat{\mathrm{Y}}=0.19+0.01 \mathrm{x} * *$ & 0.30 & 31.08 \\
\hline
\end{tabular}

** $1 \%$ probability. $1 \%$ dry matter.

The average acid detergent insoluble nitrogen content observed in the present study (18.07\%) was greater than the values reported by Roth \& Undersander (1995) as being the maximal limit (12\% acid detergent insoluble nitrogen) to characterize good-quality silage. Accordingly, there are certainly limits to the use of the nitrogen present in the silage that is partly complexed in the acid detergent fiber.

The percentage of ether extract increased with the addition of annato by-product to the elephant grass silage $(\mathrm{P}<0.01)$ and a 0.7 percentage point increase was estimated for each $1 \%$ of annato by-product added (Table 1 ). This can be explained by the greater percentage of ether extract in the annato by-product $(7.16 \%)$ compared to elephant grass $(3.9 \%)$ at ensilage. Although the annato by-product raised the ether extract percentage in the silage, it did not exceed the limit from 6 to $7 \%$ dry matter (NCR, 2001), after which there could have been interference in the ruminal fermentation, food passage rate and its digestibility.

Adding annato by-product raised the $\mathrm{pH}$ values of the silage $(\mathrm{P}<0.01)$ and a 1.01 increase was estimated in the $\mathrm{pH}$ value for each percentage unit of annato by-product added (Table 1). Despite the increase in the $\mathrm{pH}$ in the silages, the values were within the ideal range from 3.8 to 4.2 suggested by McDonald (1981) for well preserved silages, restricting proteolytic enzyme action of the plant and inhibiting development of bacteria of the Clostridium genus (Muck, 1988).

A quadratic effect $(\mathrm{P}<0.01)$ was observed in the annato by-product addition levels, where the ammonia nitrogen contents $(\%$ total $\mathrm{N})$ presented a $9.55 \%$ minimum value with the addition of $10 \%$ annato by-product. According to the regression study the ammonical nitrogen contents $(\%$ total $\mathrm{N}$ ) were lower than $12 \%$ up to the $16 \%$ inclusion level, which according to Silveira (1975) indicated a proper fermentation process.

Contents of lactic, acetic and butyric acids were similar among the silages $(\mathrm{P}<0.05)$ with mean values of $4.40 \pm 0.86$; $0.47 \pm 0.15$ and $0.03 \pm 0.06 \%$, respectively (Table 2 ).
According to Roth \& Undersander,(1995), 4\% dry matter is the minimal content of lactic acid that guarantees a fast fall in $\mathrm{pH}$ and inhibition of undesirable fermentation.

The acetic acid contents in all the silages were below the $0.8 \%$ critical level reported by Mahanna (1997). Above this level, undesirable fermentations occur, such as those resulting from the action of the Coliforme genus bacteria, heterofermentative lactic bacteria and Clostridic bacteria.

The percentage of propyonic acid increased with the addition of annato by-product to the silage and an increase of 0.01 percentage points was estimated for each $1 \%$ addition of annato by-product, but it did not interfere in the silage quality because the contents obtained in the present study were considered low, according to Roth \& Undersander, (1995).

The presence of butyric acid in the silage material is related to the depressive effect of the Clostridium genus bacteria, with significant losses in silage quality and consequently reduced acceptability and intake (Wilkinson, 1983). In the present study the butyric acid contents were compatible with good-quality silage, according to Roth \& Undersander, (1995), who reported the $0.1 \%$ content level as critical. Becauseall the silages studied presented contents lower than this value, they were classified as good-quality.

\section{Conclusions}

Annato by-product improved the silage chemical characteristics without damaging the fermentation process. Levels up to $16 \%$ of the natural matter at the time of grass ensilage are recommended, depending on the availability and cost of the annato by-product.

\section{Referências}

BOLSEN, K.K.; LIN, C.; BRENT, B.E. et al. Effect of silage additives on the microbial succession and fermentation process 
of alfafa and corn silages. Journal of Dairy Science, v.75, p.3066-3083, 1992.

CANDIDO, M.J.D.; NEIVA, J.N.M.; RODRIGUEZ, N.M. et al.. Características fermentativas e composição química de silagens de capim-elefante contendo subproduto desidratado do maracujá. Revista Brasileira de Zootecnia, v.36, p.489-1494, 2007.

CÂNDIDO, M.J.D. Qualidade e valor nutritivo de silagens de híbridos de sorgo (Sorghum bicolor (L.) Moench) sob doses crescentes de recomendação de adubação. 2000. 55f. Dissertação (Mestrado em Zootecnia) - Universidade Federal de Viçosa, Viçosa, MG.

COAN, R.M.; REIS, R.A.; GARCIA, G.R. et al. Dinâmica fermentativa e microbiológica de silagens dos capins tanzânia e marandu acrescidas de polpa cítrica peletizada. Revista Brasileira Zootecnia, v.36, n.5, p.1502-1511, 2007 (sup1.).

CYSNE, J.R.B.; NEIVA, J.N.M.; CANDIDO, M.J.D. et al. Composição químico-bromatológica e características fermentativas de silagens de capim elefante contendo níveis crescentes do subproduto da Graviola. Revista Ciência Agronômica, v.37, p.376-380, 2006.

EVANGELISTA, A.R.; LIMA, J.A.; BERNARDES, T.F. Avaliação de Algumas Características da Silagem de Gramínea Estrela Roxa (Cynodon nlemfuensis Vanderyst). Revista Brasileira de Zootecnia, v.29, n.4, p.941-946, 2000

FERREIRA, A.C.H. ; RODRIGUEZ, N.M.; NEIVA, J.N.M. et al. Características químico bromatológicas e fermentativas do capim elefante ensilado com níveis crescentes de subproduto da agroindústria do abacaxi. Revista Ceres, v.54, p.98-106, $2007 \mathrm{a}$.

FERREIRA, A.C.H. ; NEIVA, J.N.M. ; RODRIGUEZ, N.M. et al. Características químicas e fermentativas do capim-elefante ensilado com níveis crescentes de subproduto da agroindústria do caju. Ciência Animal Brasileira, v.8, p.723-731, $2007 \mathrm{~b}$.

GONÇALVES, J.S.; NEIVA, J.N.M.; CÂNDIDO, M.J.D. et al. Composição bromatológica e características fermentativas de silagens de capim-elefante (Pennisetum purpureum Schum.) cv. Roxo contendo níveis crescentes do subproduto da semente de urucum (Bixa orellana L.). Revista Ciência Agronômica, v. 37, n.2, p.228-234, 2006

GONÇALVES, J.S.; NEIVA, J.N.M.; VIEIRA, N.F. et al. Valor nutritivo de silagens de capim-elefante (Pennisetum purpureum Schum.) com adição de diferentes níveis dos subprodutos do processamento de acerola (Malpighia glabra L.) e de goiaba (Psidium guajava L.). Revista Ciência Agronômica, v.35, n.1, p.131-137, 2004b.

GONÇALVES, J.S., NEIVA, J.N.M., OLIVEIRA FILHO, G.S. et al. Valor nutritivo de silagens de capim elefante (Pennisetum purpureumShum) e Brachiaria decumbens contendo pedúnculo de caju (Annacardium occidentale L.) desidratado. Revista Ciência Agronômica, v.38, n.2, p.204-209, 2007.

HALL, M.B. Recent advanced in non-ndf carbohydrates for the nutrition of lactating cows. In: SIMPÓSIO INTERNACIONAL EM BOVINOS DE LEITE: Novos conceitos em nutrição, 2., Lavras, 2001. Anais... Lavras: Universidade Federal de Lavras, 2001. p.139-148.

JUNG, H.G.; ALLEN, M.S. Characteristics of plant cell walls affecting intake and digestibility of forages by ruminants. Journal of Animal Science, v.73, n.9, p.2774-2790, 1995.

MAHANNA, B. [1997]. Troubleshooting silage problems. Disponível em: <http:/www.pioneer.com/xweb>. Acesso em: 23/03/2009.

MATHEW, S.; SAGATHEVAN, S.; THOMAS, J. et al. An HPLC method for estimation of volatile fatty acids in ruminal fluid. Indian Journal of Animal Science, v.67, n.9, p.805-807, 1997.

McCULlOUGH, M.E. Silage and silage fermentation. Feedstuffs, v.13, n.49, p.49-52, 1977.
McDONALD, P. The biochemistry of silage. New York: John Willey \& Sons, 1981. 226p.

MUCK, R.E. Factors influencing silage quality and their implications for management. Journal of Dairy Science, v.71, n.11, p.2992-3002, 1988.

NATIONAL RESEARCH COUNCIL - NRC. Nutrient requirements of dairy cattle. 7.ed. Washington: National Academy Press, 2001. 362p.

NEIVA, J.N.M.; NUNES, F.C.S.; CANDIDO, M.J.D. et al. Valor nutritivo de silagens de capim elefante enriquecidas com subprodutos do processamento de maracuja. Revista Brasileira de Zootecnia, v.35, p.1843-1849, 2006.

NUSSIO, L.G., PAZIANI, S.F., NUSSIO, C.M.B. Ensilagem de capins tropicais. In: REUNIÃO ANUAL DA SOCIEDADE BRASILEIRA DE ZOOTECNIA, 39., 2002, Recife. Anais.. Recife: Sociedade Brasileira de Zootecnia, 2002. p.60-90.

POMPEU, R. C. F. F. ; NEIVA, J. N. M.; CANDIDO, M. J. D. et al. Valor nutritivo de silagens de capim-elefante (Pennisetum purpureumSchum.) com adição de subprodutos do processamento de frutas tropicais. Revista Ciência Agronômica, v.37, n.1, p.77-83, 2006

RESENDE, F.D.; QUEIROZ, A.C.; FONTES, C.A. et al. Rações com diferentes níveis de fibra em detergente neutro na alimentação de bovídeos em confinamento. Revista Brasileira de Zootecnia, v.23, n.3, p.366-376, 1994.

RIBEIRO, J.L.; NUSSIO, L.G.; MOURÃO, G.B. Efeitos de absorventes de umidade e de aditivos químicos e microbianos sobre ovalor nutritivo, o perfil fermentativo e as perdas em silagens de capim-marandu. Revista Brasileira de Zootecnia, v.38, n.2, p.230-239, 2009

ROTH, G.; UNDERSANDER, D. Silage additives. In: Corn silage production management and feeding. Madison American Society of Agronomy, 1995. p.27-29.

SÁ, C.R.L.; NEIVA, J.N.M.; GONÇALVES, J.S. et al. Composição bromatológica e características fermentativas de silagens de capim elefante (Pennisetum purpureum Schum.) com níveis crescentes de adição do subproduto da Manga (Mangifera indica L.). Revista Ciência Agronômica, v.38, n.2, p.199-203, 2007.

SILVA, C.; LEÃO, M.I. Fundamentos de nutrição dos ruminantes. Piracicaba, Livroceres, 1979. p.190-236.

SILVA, D.J.; QUEIROZ, A.C. Análise de alimentos: métodos químicos e biológicos. 2.ed. Viçosa, MG: UFV, 2002. 165p.

SILVEIRA, A.C. Técnicas para produção de silagens. In: SIMPÓSIO SOBRE MANEJO DA PASTAGEM, 1975, Piracicaba. Anais.. Piracicaba: ESALQ, 1975. p.156-186.

SNIFFEN, C.J.; O'CONNOR, J.D.; VAN SOEST, P.J. A net carbohydrate and protein system for evaluating cattle diets: II. carbohydrate and protein availability. Journal of Animal Science, v.70, n.11, p.3562-3577, 1992.

SOUZA, I.; FARIA, J.O. A cultura do urucum. [2000]. Disponível em: <http://www.ruralnews.com.br>. Acesso em: 22/8/2004.

STATISTICAL ANALYSES SYSTEM - SAS. User's guide. Cary: SAS Institute, 2001. 1028p.

TAVARES, V.B.; PINTO, J.C.; EVANGELISTA, A.R. Efeitos da compactação, da inclusão de aditivo absorvente e do emurchecimento na composição bromatológica de silagens de capim-tanzânia. Revista Brasileira de Zootecnia, v.38, n.1, p.40-49, 2009

TOSI, P.; MATTOS, W.R.S.; TOSI, H. et al. Avaliação do capimelefante (Pennisetum purpureum Schum.) cultivar Taiwan A-148, ensilado com diferentes técnicas de redução de umidade. Revista Brasileira de Zootecnia, v.28, n.5, p.947-954, 1999.

VAN SOEST, P.J. Nutritional ecology of the ruminant. 2.ed. Ithaca, New York: Cornell University Press, 1994. 476p.

WILKINSON, J.M. Silage made from tropical and temperate crops. 2. Techniques for improving the nutritive value of silage. World Animal Review, v.46, p.35-40, 1983. 